\title{
PERILAKU KONSUMEN DALAM PEMBELIAN BERAS SIGER DI KELOMPOK WANITA TANI MELATI PEKON MARGOSARI KECAMATAN PAGELARAN UTARA
}

\author{
(Consumer Behavior in Purchasing Siger Rice at Woman Farmers Group Melati Pekon Margosari \\ Kecamatan Pagelaran Utara)
}

Novia Setyaningrum, Bustanul Arifin, Zainal Abidin

\begin{abstract}
Jurusan Agribisnis, Fakultas Pertanian, Universitas Lampung, J1. Prof. Dr. Soemantri Brojonegoro No. 1 Bandar Lampung 35141, e-mail: bustanul.arifin@fp.unila.ac.id
\end{abstract}

\begin{abstract}
This study aims at analyzing consumers attitudes towards attributes of Siger Rice, consumer decisionmaking processes in the purchase of Siger Rice and dominant factors that influence the decision in purchasing Siger Rice. Data collection was conducted from January to April 2019. The sampling technique used in the study was snowballing sampling. The number of samples in this study were 38 housewives who met the criteria of buying and consuming Siger Rice. The first objective was analyzed by the Fishbein Multiattribute Model, the second objective was analyzed by qualitative descriptive analysis, and the third objective was analyzed by analysis of the main components. The results showed that the taste attribute got the highest attitude score of 18.96, while the ease of obtaining attribute had the lowest attitude score of 11.87. The process of making Siger Rice purchase decisions by consumers were through all stages, the need recognition, information searching, evaluation of alternatives, purchase decisions and post-purchase evaluation. There are three dominant components that influence the purchasing decision of Siger rice, i.e. the price conformity, attractiveness, and habit.
\end{abstract}

Key words: analysis of main components, consumer attitudes, consumer behavior, siger rice.

\section{PENDAHULUAN}

Pangan merupakan kebutuhan dasar manusia yang paling utama selain sandang, papan, pendidikan dan kesehatan. Pangan berfungsi sebagai sumber tenaga manusia untuk keberlanjutan hidup seharihari. Menurut Undang-Undang Nomor 18 Tahun 2012 Pasal I tentang Pangan menyatakan bahwa ketahanan pangan adalah kondisi terpenuhinya pangan bagi negara sampai dengan perseorangan, yang tercermin dari tersedianya pangan yang cukup, baik jumlah maupun mutunya, aman, beragam, bergizi. Pada kenyataannya, saat ini masyarakat di Indonesia umumnya dan di Provinsi Lampung, khususnya Kabupaten Pringsewu belum mampu mencapai kondisi ketahanan pangan, dikarenakan tiga komponen utama ketahanan pangan yaitu ketersediaan, akses, dan pemanfaatan pangan belum memadai.

Tingkat konsumsi beras di Kabupaten Pringsewu masih tinggi, dikarenakan adanya persepsi masyarakat yang menganggap bahwa beras merupakan satu-satunya bahan pokok yang mengandung karbohidrat paling tinggi. Kebiasaan mengonsumsi beras sejak kecil juga menjadi alasan akan ketergantungan masyarakat terhadap beras. Upaya pemerintah untuk mengatasi rendahnya ketersediaan pangan, adalah menerbitkan Peraturan Presiden (Perpres) Nomor 22 Tahun 2009 tentang Kebijakan Percepatan Penganekaragaman Konsumsi Pangan Berbasis Sumberdaya Lokal.

Implementasi dari Perpres dan Permentan Nomor 43 Tahun 2019, Kementerian Pertanian melalui Badan Ketahanan Pangan sejak tahun 2010 meluncurkan program Percepatan Penganekaragaman Konsumsi Pangan (P2KP) untuk mempercepat diversifikasi pangan. Berdasarkan peraturan tersebut, maka Dinas Ketahanan Pangan Daerah Kabupaten Pringsewu berkomitmen untuk menyukseskan Gerakan P2KP melalui salah satu programnya yaitu Model Pengembangan Pangan Pokok Lokal (MP3L) yang diaplikasikan melalui pengembangan produk olahan dari ubi kayu menjadi tiwul modifikasi atau yang dikenalkan dengan nama Beras Siger.

Kelompok Wanita Tani (KWT) Melati Pekon Margosari Kecamatan Pagelaran Utara merupakan produsen Beras Siger yang ditunjuk oleh Dinas Ketahanan Pangan Daerah Kabupaten Pringsewu sebagai pelaksana program MP3L yang berada di Pekon Margosari Kecamatan Pagelaran Utara. Produk yang dihasilkan adalah Beras Siger berwarna putih. 
KWT Melati memiliki permasalahan utama yaitu di bidang pemasaran. Harga jual Beras Siger yang relatif mahal, yaitu berkisar antara Rp10.000,Rp15.000, harga tersebut tidak jauh berbeda dengan harga beras, sehingga masih sedikit masyarakat yang beralih untuk mengonsumsi Beras Siger, meskipun kandungan Beras Siger baik untuk tubuh. Sulitnya pemasaran Beras Siger juga mengakibatkan penjualan Beras Siger berfluktuasi, sehingga menyebabkan produsen sulit mendapatkan modal untuk kegiatan produksi berikutnya.

Segmen pasar yang terbatas, menyebabkan Beras Siger kurang diketahui oleh masyarakat umum dan menyebabkan sulitnya Beras Siger untuk dijual. Oleh karena itu, dalam pemasaran Beras Siger perlu ditinjau lebih dahulu perilaku konsumen. Menurut Peter dan Olson (1999), kajian perilaku konsumen dapat dijadikan dasar untuk menganalisis lingkungan bisnis.

Aspek perilaku konsumen yang perlu diketahui oleh pelaku usaha adalah sikap, proses pengambilan keputusan dan faktor-faktor dominan yang mempengaruhi keputusan pembelian, karena dapat menjadi landasan yang penting di dalam pemasaran, sehingga dapat membidik pembeli secara lebih terarah. Sikap konsumen merupakan evaluasi dari seseorang, ungkapan perasaan konsumen suka atau tidak suka terhadap Beras Siger. Atribut Beras Siger yang diduga mempengaruhi konsumen dalam menentukan keputusan pembelian meliputi, harga, rasa, warna, aroma, kekenyalan, kemasan, label dan kemudahan memperoleh.

Terdapat lima proses pengambilan keputusan yang dilalui oleh setiap individu yaitu pengenalan kebutuhan, pencarian informasi, evaluasi alternatif, keputusan pembelian dan pasca pembelian (Kotler dan Keller, 2009). Faktor-faktor yang mempengaruhi keputusan pembelian terdiri dari faktor lingkungan meliputi budaya $\left(\mathrm{X}_{1}\right)$, kelas sosial $\left(\mathrm{X}_{2}\right)$, pengaruh orang lain $\left(\mathrm{X}_{3}\right)$. Faktor individu terdiri dari sumber daya konsumen $\left(\mathrm{X}_{4}\right)$, gaya hidup $\left(\mathrm{X}_{5}\right)$,dan pengetahuan $\left(\mathrm{X}_{6}\right)$. Faktor psikologi berasal dari pengalaman $\left(\mathrm{X}_{7}\right)$ melalui proses pembelajaran konsumen dan atribut Beras Siger.

Berdasarkan uraian sebelumnya, penelitian ini bertujuan untuk menganalisis sikap konsumen terhadap atribut Beras Siger, proses pengambilan keputusan konsumen dalam pembelian Beras Siger dan faktor-faktor dominan yang mempengaruhi konsumen dalam membeli Beras Siger pada KWT Melati.

\section{METODE PENELITIAN}

Penelitian ini dilakukan menggunakan metode survei dan dilaksanakan secara sengaja di Kelompok Wanita Tani (KWT) Melati yang terletak di Pekon Margosari Kecamatan Pagelaran Utara, dengan. pertimbangan KWT tersebut merupakan KWT yang memproduksi Beras Siger dengan bahan baku berasal dari ubi kayu (singkong segar) dan menghasilkan warna Beras Siger putih mirip dengan beras. Pengambilan data dilakukan pada bulan Januari hingga April 2019.

Pengambilan sampel pada penelitian ini menggunakan metode snowball sampling yaitu penentuan sampel dengan penelusuran sampel melalui informasi yang diperoleh dari sampel sebelumnya. Batasan khusus untuk konsumen yang digunakan sebagai sampel adalah ibu rumah tangga yang melakukan pembelian dan mengonsumsi produk Beras Siger dari KWT Melati. Konsumen dalam penelitian ini berjumlah 38 orang, dengan pertimbangan bahwa masih sedikit masyarakat yang mengonsumsi Beras Siger dan populasi nyata konsumen Beras Siger KWT Melati lainnya tidak diketahui berapa jumlahnya. Pengumpulan data dengan cara wawancara menggunakan kuisioner.

Metode analisis yang digunakan untuk menjawab tujuan pertama yaitu analisis sikap konsumen dengan Model Multiatribut Fishbein dan dijelaskan dengan rumus menurut Suryani (2012) :

$\mathrm{A}_{\mathrm{O}}=\sum_{\mathrm{i}=1}^{\mathrm{n}}$ bi.ei

Keterangan :

$\mathrm{A}_{\mathrm{o}} \quad=$ Sikap terhadap suatu objek

bi = Kekuatan kepercayaan bahwa objek tersebut memiliki atribut $\mathrm{i}$

ei $=$ Evaluasi terhadap atribut $\mathrm{i}$

$\mathrm{n} \quad=$ Jumlah atribut yang dimiliki objek

Variabel $A_{o}$ merupakan multi sikap konsumen terhadap Beras Siger, yang diperoleh dari jumlah hasil perkalian setiap skor evaluasi (ei) dengan skor kepercayaan (bi) konsumen terhadap atribut Beras Siger. Komponen (ei) adalah evaluasi kepentingan atribut-atribut yang terdapat pada produk Beras Siger yang diukur dengan skor (5) sangat penting, (4) penting, (3) cukup penting, (2) tidak penting, (1) sangat tidak penting. Komponen 
(bi) diukur dengan ketentuan skor sama dengan skor evaluasi (ei) untuk atribut harga diukur dengan skor (5) sangat murah, (4) murah, (3) cukup murah, (2) tidak murah, (1) sangat tidak murah. Rasa diukur dengan skor (5) sangat enak, (4) enak, (3) cukup enak, (2) tidak enak, (1) sangat tidak enak. Warna diukur dengan skor (5) sangat mirip, (4) mirip, (3) cukup mirip, (2) tidak mirip, (1) sangat tidak mirip. Aroma diukur dengan skor (5) sangat tidak khas, (4) tidak khas, (3) cukup khas, (2) khas, (1) sangat khas. Kekenyalan diukur dengan skor (5) sangat tidak kenyal, (4) tidak kenyal, (3) cukup kenyal, (2) kenyal, (1) sangat kenyal. Kemasan diukur dengan skor (5) sangat menarik, (4) menarik, (3) cukup menarik, (2) tidak menarik, (1) sangat tidak menarik. Label diukur dengan skor (5) sangat bermanfaat, (4) bermanfaat, (3) cukup bermanfaat, (2) tidak bermanfaat, (1) sangat tidak bermanfaat. Kemudahan memperoleh diukur dengan skor (5) sangat mudah, (4) mudah, (3) cukup mudah, (2) sulit, (1) sangat sulit.

Kuesioner sebelum digunakan terlebih dahulu diuji validitas yang bertujuan untuk mengetahui ketepatan pertanyaan yang diajukan, serta diuji reliabilitas yang bertujuan untuk mengetahui konsistensi kuesioner, sehingga hasil suatu pengukuran dapat dipercaya. Berdasarkan hasil uji validitas menunjukkan bahwa atribut rasa, harga, warna, aroma, kekenyalan, kemasan, label dan kemudahan memperoleh memiliki nilai $r>0,20$ atau dapat dikatakan semua butir pertanyaan dalam kuesioner tersebut valid. Selanjutnya, kuisioner diuji reliabilitasnya.

Menurut Sufren dan Natael (2013), penggunaan teknik Alpha-Cronbach akan menunjukkan bahwa suatu instrumen dapat dikatakan handal (reliabel) bila memiliki koefisien reliabilitas sebesar 0,60 atau lebih. Nilai uji reliabilitas pada kuesioner kepercayaan yang diperoleh adalah 0,74 sedangkan pada kuesioner evaluasi memperoleh nilai uji reliabilitas sebesar 0,77 , sehingga, dapat disimpulkan bahwa butir pertanyaan dalam kuesioner tersebut reliabel.

Metode analisis data yang digunakan untuk menjawab tujuan kedua adalah analisis deskriptif kualitatif dengan mendeskripsikan kelima tahapan proses pengambilan keputusan konsumen rumah tangga dalam pembelian Beras Siger di KWT Melati. Metode analisis data yang digunakan untuk menjawab tujuan ketiga adalah analisis komponen utama pada penelitian ini dirotasi dengan rotasi varimax, karena akan lebih mudah diinterpretasikan dan memberikan hasil yang lebih baik. Penentuan skor variabel pada analisis komponen utama menggunakan skala Likert 1-5 dengan keterangan nilai 5 (sangat setuju), 4 (setuju), 3 (netral), 2 (tidak setuju), 1 (sangat tidak setuju).

Menurut Supranto (2010), model analisis faktor dapat dirumuskan sebagai berikut:

$\mathrm{F}_{\mathrm{i}}=\mathrm{W}_{\mathrm{i} 1} \mathrm{X}_{1}+\mathrm{W}_{\mathrm{i} 2} \mathrm{X}_{2}+\mathrm{W}_{\mathrm{i} 3} \mathrm{X}_{3}+\ldots .+\mathrm{Wi}_{\mathrm{k}} \mathrm{X}_{\mathrm{k}}$

Keterangan :

$F_{i}=$ Faktor Principal Component

$W_{i}=$ Timbangan atau koefisien nilai faktor ke $\mathrm{i}$

$K$ = Banyaknya variabel

Sebelum dilakukan analisis komponen utama, terlebih dahulu dilakukan uji validitas dan reliabilitas terhadap 15 variabel antara lain yaitu budaya $\left(\mathrm{X}_{1}\right)$, kelas sosial $\left(\mathrm{X}_{2}\right)$, pengaruh orang lain $\left(\mathrm{X}_{3}\right)$, sumber daya konsumen $\left(\mathrm{X}_{4}\right)$, gaya hidup $\left(\mathrm{X}_{5}\right)$, pengetahuan $\left(\mathrm{X}_{6}\right)$, pengalaman $\left(\mathrm{X}_{7}\right)$, harga $\left(\mathrm{X}_{8}\right)$, rasa $\left(\mathrm{X}_{9}\right)$, warna $\left(\mathrm{X}_{10}\right)$, aroma $\left(\mathrm{X}_{11}\right)$, kekenyalan $\left(\mathrm{X}_{12}\right)$, kemasan $\left(\mathrm{X}_{13}\right)$, label $\left(\mathrm{X}_{14}\right)$, dan kemudahan memperoleh produk $\left(\mathrm{X}_{15}\right)$. Hasil uji validitas dan reliabilitas dapat dilihat pada Tabel 1.

Tabel 1. Hasil uji validitas dan reliabilitas variabel faktor dominan dalam pembelian Beras Siger KWT Melati

\begin{tabular}{clcc}
\hline No & $\begin{array}{c}\text { Variabel yang di } \\
\text { uji }\end{array}$ & $\begin{array}{c}\text { Corrected } \\
\text { item total } \\
\text { Correlation }\end{array}$ & Keterangan \\
\hline 1 & Budaya $\left(\mathrm{X}_{1}\right)$ & 0,13 & Tidak valid \\
2 & Kelas sosial $\left(\mathrm{X}_{2}\right)$ & 0,01 & Tidak valid \\
3 & Pengaruh orang & 0,38 & Valid \\
& lain $\left(\mathrm{X}_{3}\right)$ & & Tidak valid \\
4 & Sumberdaya & 0,09 & \\
& konsumen $\left(\mathrm{X}_{4}\right)$ & & Valid \\
5 & Gaya hidup $\left(\mathrm{X}_{5}\right)$ & 0,39 & Valid \\
6 & Pengetahuan $\left(\mathrm{X}_{6}\right)$ & 0,23 & Valid \\
7 & Pengalaman $\left(\mathrm{X}_{7}\right)$ & 0,42 & Valid \\
8 & Harga $\left(\mathrm{X}_{8}\right)$ & 0,32 & Valid \\
9 & Rasa $\left(\mathrm{X}_{9}\right)$ & 0,51 & Valid \\
10 & Warna $\left(\mathrm{X}_{10}\right)$ & 0,25 & Valid \\
11 & Aroma $\left(\mathrm{X}_{11}\right)$ & 0,61 & Valid \\
12 & Kekenyalan $\left(\mathrm{X}_{12}\right)$ & 0,45 & Valid \\
13 & Kemasan $\left(\mathrm{X}_{13}\right)$ & 0,53 & Valid \\
14 & Label $\left(\mathrm{X}_{14}\right)$ & 0,3 & Valid \\
15 & Kemudahan & 0,28 & \\
& Memperoleh $\left(\mathrm{X}_{15}\right)$ & & 0,72 \\
\hline & Hasil uji & & \\
& reliabilitas & & \\
& Cronbach Alpha & & \\
\hline & & & \\
\hline
\end{tabular}




\section{HASIL DAN PEMBAHASAN}

\section{Karakteristik Responden Produsen Beras Siger}

Responden produsen Beras Siger adalah Ibu Ani Nurwanti selaku ketua KWT Melati. Ibu Ani berusia 42 tahun. Tingkat pendidikan yang dicapai Ibu Ani adalah Sekolah Menengah Atas (SMA), Ibu Ani memiliki pengalaman usaha selama 5 tahun. Responden mendapatkan pengalaman usaha secara otodidak dan melalui pelatihan pembuatan Beras Siger yang dilakukan oleh pemerintah.

\section{Karakteristik Responden Konsumen Beras Siger}

Usia responden pada penelitian ini berkisar antara 22 sampai dengan 58 tahun, mayoritas konsumen bersuku jawa dengan persentase sebesar 76,32 persen. Tingkat pendidikan konsumen mayoritas tamat SMA dengan persentase sebesar 50,00 persen. Mayoritas konsumen berprofesi sebagai PNS dengan persentase sebesar 36,84 persen. Pendapatan rumah tangga mayoritas berkisar antara Rp1.000.000 - Rp2.000.000 dengan persentase sebesar 36,84 persen. Jumlah anggota keluarga konsumen Beras Siger berkisar antara 4-5 orang dengan persentase sebesar 78,95 persen.

\section{Sikap Konsumen Rumah Tangga Terhadap Beras Siger}

Sikap merupakan evaluasi dari seseorang, ungkapan perasaan konsumen suka atau tidak suka terhadap Beras Siger, karena sikap yang positif akan menghasilkan pembelian, bukan saja dari konsumen yang bersangkutan, tetapi rekomendasi kepada teman-teman maupun keluarganya juga akan membuahkan pembelian. Sikap konsumen rumah tangga terhadap Beras Siger diketahui melalui penilaian konsumen berdasarkan kepercayaan $\left(b_{i}\right)$ dan evaluasi $\left(e_{i}\right)$ terhadap atributatribut Beras Siger.

Berdasarkan nilai kepercayaan dan evaluasi konsumen atas masing-masing atribut, maka diperoleh nilai sikap multiatribut Fishbein. Untuk memperoleh nilai Indeks sikap konsumen $\mathrm{A}_{\mathrm{o}}$ didapatkan dengan menjumlahkan skor kepercayaan bi dan skor evaluasi ei. Penilaian sikap konsumen ini bertujuan untuk mengetahui bagaimana sikap konsumen terhadap Beras Siger berdasarkan atribut-atribut yang dimilikinya. Nilai indeks sikap konsumen $\mathrm{A}_{\mathrm{o}}$ dapat dilihat pada Tabel 2.
Tabel 2. Nilai indeks sikap konsumen $A_{\circ}$ Beras Siger KWT Melati

\begin{tabular}{|c|c|c|c|c|}
\hline No & Atribut & bi & ei & bi $x$ ei \\
\hline 1 & Rasa & 4,26 & 4,45 & 18,96 \\
\hline 2 & Aroma & 3,95 & 4,18 & 16,52 \\
\hline 3 & Kemasan & 4,24 & 3,89 & 16,50 \\
\hline 4 & Label & 4,21 & 3,82 & 16,07 \\
\hline 5 & Kekenyalan & 3,55 & 4,03 & 14,30 \\
\hline 6 & Harga & 3,32 & 4,16 & 13,79 \\
\hline 7 & Warna & 3,58 & 3,74 & 13,37 \\
\hline \multirow[t]{2}{*}{8} & $\begin{array}{l}\text { Kemudahan } \\
\text { Memperoleh }\end{array}$ & 2,68 & 4,42 & 11,87 \\
\hline & Nilai sikap $(A$ & & & 121,38 \\
\hline
\end{tabular}

Nilai sikap multiatribut Fishbein konsumen terhadap Beras Siger sebesar 121,38. Atribut rasa memiliki nilai sikap atribut tertinggi bagi konsumen. Hal ini menunjukkan bahwa rasa Beras Siger yang enak dan tidak jauh berbeda dari beras, hanya saja karena berasal dari ubi kayu maka Beras Siger mempunyai cita rasa yang sangat unik.

Atribut harga menjadi urutan yang ke enam. Hal ini dikarenakan menurut sebagian besar konsumen menganggap bahwa harga Beras Siger cukup terjangkau, konsumen juga tidak terlalu mementingkan harga, karena konsumen mencari manfaat kesehatan dari mengonsumsi Beras Siger.

Hasil penelitian ini berbeda dengan hasil penelitian Parastry, Lestari dan Prasmatiwi (2016) yang menyatakan bahwa atribut harga memiliki nilai sikap atribut tertinggi bagi konsumen Toga Sari dan Mekar Sari. Hal ini menunjukkan bahwa harga menjadi atribut yang paling dipentingkan oleh konsumen, karena harga Beras Siger yang relatif terjangkau oleh konsumen.

\section{Proses Pengambilan Keputusan Pembelian Beras Siger di KWT Melati}

Karakteristik konsumen yang beragam tentu akan mempengaruhi setiap pribadi konsumen dalam proses pengambilan keputusan dan pembelian produk atau menggunakan suatu jasa. Proses pengambilan keputusan terdiri dari lima tahapan, yaitu tahapan pengenalan kebutuhan, tahapan pencarian informasi, tahapan evaluasi alternatif, tahapan keputusan pembelian dan tahapan evaluasi pasca pembelian.

Pada tahap pengenalan kebutuhan, motivasi utama konsumen Beras Siger membeli dan mengonsumsi Beras Siger, karena alasan kesehatan sebesar 63,16 persen, motivasi yang kedua yaitu konsumen 
menikmati sensasi Beras Siger sebesar 36,84 persen, menurut beberapa konsumen setelah mengonsumsi Beras Siger, ada sesuatu yang beda dan ingin mengonsumsinya kembali.

Manfaat utama yang dicari konsumen setelah membeli dan mengonsumsi Beras Siger adalah perwujudan gaya hidup sehat sebesar 57,89 persen. Hal ini membuktikan bahwa konsumen menginginkan kesehatan dengan memulai memilih makanan yang sehat. Hasil penelitian ini sejalan dengan penelitian yang dilakukan Parastry, dkk (2016) yang menyebutkan bahwa konsumen termotivasi mengonsumsi Beras Siger, karena alasan manfaat yang diperoleh sebesar 61,20 persen konsumen Toga Sari dan 75,00 persen konsumen Mekar Sari.

Pada tahap pencarian informasi, sumber informasi konsumen mengenai Beras Siger sebagian besar berasal dari keluarga sebesar 34,21 persen. Hasil penelitian ini sejalan dengan penelitian yang dilakukan Mukti, Utomo, dan Subekti (2017) yang menyebutkan bahwa sebagian besar konsumen mendapatkan informasi mengenai Beras Siger dari anggota keluarga dengan persentase 50,00 persen yang sudah terlebih dahulu mengonsumsi Beras Siger, yang kemudian merekomendasikan kepada teman untuk mencobanya.

Manfaat dari Beras Siger menarik perhatian utama konsumen dengan persentase 32,89 persen. Hal ini menunjukan bahwa konsumen tidak sembarangan mengonsumsi makanan, konsumen memilih produk yang memberikan manfaat untuk kesehatan. Rasa dari Beras Siger menarik perhatian kedua dengan persentase 21,05 persen. Konsumen menyatakan rasa dari Beras Siger enak.

Pihak yang paling mempengaruhi konsumen dalam membeli dan mengonsumsi Beras Siger adalah keluarga dengan persentase sebesar 50,00 persen. Pihak kedua yang mempengaruhi pembelian Beras Siger adalah diri sendiri dengan persentase sebesar 44,74 persen.

Pada tahap evaluasi alternatif, dimana konsumen menggunakan informasi yang telah ia peroleh mengenai Beras Siger di KWT Melati untuk mengevaluasi atribut yang dapat menjadi pertimbangan pembelian. Pertimbangan utama konsumen dalam pembelian Beras Siger sebelum melakukan pembelian adalah manfaat dengan persentase 81,58 persen dan harga menjadi pertimbangan kedua konsumen dalam melakukan pembelian dengan persentase 18,42 persen.
Kriteria utama yang menunjukan kualitas Beras Siger KWT Melati menurut sebagian besar konsumen adalah rasa dengan persentase 71,05 persen, kriteria yang kedua adalah harga dengan persentase sebesar 15,79 persen dan kemasan menjadi kriteria yang menunjukan kualitas yang terakhir.

Pada proses keputusan pembelian, konsumen melakukan pembelian dalam jumlah yang berbeda-beda. Mayoritas konsumen melakukan pembelian Beras Siger sebanyak sebanyak lebih dari empat kg dengan persentase 26,32 persen.

Cara pembelian konsumen terbagi menjadi tiga, yaitu pembelian secara terencana, tergantung situasi, dan secara mendadak atau pembelian yang tidak direncanakan terlebih dahulu. Cara pembelian Beras Siger oleh konsumen sebagian besar dilakukan tergantung situasi dengan persentase sebesar 52,63 persen, dimana mereka membeli Beras Siger pada saat KWT Melati memiliki stok Beras Siger. Hasil penelitian ini sejalan dengan penelitian yang dilakukan Parastry, dkk (2016) yang menyebutkan bahwa mayoritas konsumen Toga Sari melakukan keputusan pembelian Beras Siger tergantung pada situasi stok Beras Siger yang dimiliki sebesar 59,20 persen, sedangkan pada konsumen Mekar Sari yaitu sebesar 57,50 persen.

Pada saat proses keputusan pembelian, tindakan pertama yang dilakukan sebagian besar konsumen apabila Beras Siger di KWT Melati tidak tersedia adalah tidak jadi membeli dengan persentase sebesar 65,79 persen, karena menurut sebagian konsumen yang telah mengonsumsi Beras Siger, konsumen merasa percaya dengan kualitas Beras Siger KWT Melati.

Pada tahap evaluasi pasca pembelian, semua konsumen merasa puas akan pembelian Beras Siger KWT Melati dengan persentase 100,00 persen. Konsumen merasa puas, karena Beras Siger memiliki kualitas yang baik dan memperoleh manfaat kesehatan setelah mengonsumsinya.

Kepuasan konsumen akan Beras Siger KWT Melati dapat mempengaruhi niatnya untuk melakukan pembelian ulang konsumen dengan persentase 100,00 persen. Hasil ini sejalan dengan penelitian Ariesta, Lestari, dan Sayekti (2016) yang menyatakan bahwa hampir seluruh konsumen Beras Siger Tunas Baru merasa puas dan akan melakukan pembelian kembali. 


\section{Faktor Dominan yang Memengaruhi Pembelian}

Faktor-faktor dominan yang memengaruhi konsumen dalam membeli Beras Siger KWT Melati dianalisis menggunakan analisis komponen utama (PCA). Variabel yang digunakan untuk menganalisis berjumlah 15 (lima belas) variabel, setelah dilakukan analisis validitas dan reliabilitas variabel budaya, kelas sosial dan sumber daya konsumen memiliki nilai Corrected Item Total Correlation di bawah 0,20 sehingga ketiga variabel tersebut dinyatakan tidak valid. Variabel yang tidak valid harus dihilangkan dari daftar variabel penelitian. Maka variabel budaya, kelas sosial dan sumber daya konsumen harus dihilangkan. Hasil uji reliabilitas yang dilakukan terhadap variabel yang valid menghasilkan nilai Croanbach's Alpha sebesar 0,72. Variabel yang dianalisis menggunakan analisis faktor merupakan variabel yang dinyatakan valid pada uji validitas dan realibilitas sebelumnya, maka variabel tersebut akan diuji kelayakan data. Uji kelayakan dilakukan dengan mencari nilai Barlett Test of Sphericity dan Keiser-Meyers-Oklin (KMO). Nilai Keiser-Meyers-Oklin (KMO) Measure of Sampling Adequacy dan Bartlett's Test hasil analisis faktor dapat dilihat pada Tabel 3.

Measure of Sampling Adequacy Barlett Test of Sphericity digunakan untuk mengetahui apakah terdapat korelasi yang signifikan antar variabel, sedangkan KMO digunakan untuk mengukur kecukupan sampel yang diteliti. Analisis dikatakan layak, bila nilai KMO $\geq 0,50$ dan Barlett Test of Sphericity memiliki signifikansi di bawah 0,05 .

Tabel 3. Keiser-Meyers-Oklin (KMO) Measure of Sampling Adequacy dan Bartlett's Test hasil analisis faktor

\begin{tabular}{clc}
\hline $\begin{array}{c}\text { KMO } \\
\begin{array}{c}\text { Bartlett's Test } \\
\text { of Sphericity }\end{array}\end{array}$ & \multicolumn{1}{c}{ sig. } & 0,71 \\
\hline & Pengaruh orang & 0,00 \\
\hline & lain( $\left.\mathrm{X}_{3}\right)$ & 0,70 \\
& Gaya hidup $\left(\mathrm{X}_{5}\right)$ & 0,54 \\
& Harga $\left(\mathrm{X}_{8}\right)$ & 0,59 \\
& Rasa $\left(\mathrm{X}_{9}\right)$ & 0,78 \\
& Warna $\left(\mathrm{X}_{10}\right)$ & 0,73 \\
& Aroma $\left(\mathrm{X}_{11}\right)$ & 0,77 \\
& Kekenyalan $\left(\mathrm{X}_{12}\right)$ & 0,79 \\
& Kemasan $\left(\mathrm{X}_{13}\right)$ & 0,68 \\
& Label $\left(\mathrm{X}_{14}\right)$ & 0,69 \\
& Kemudahan & \\
& memperoleh $\left.\mathrm{X}_{15}\right)$ & 0,58 \\
\hline
\end{tabular}

Nilai Keiser-Meyers-Oklin (KMO) Measure of Sampling Adequacy dan tingkat signifikansi Barlett's Test berubah-ubah pada setiap analisis. Pada analisis pertama, diperoleh nilai KMO MSA 0,65 yang artinya lebih besar dari 0,50 . Sementara itu, signifikansi yang dihasilkan dari Bartlett's Test of Sphericity sebesar 0,00.

Nilai MSA dari variabel pengalaman $\left(X_{7}\right)$ kurang dari 0,50 sehingga variabel tersebut harus dikeluarkan. Pada analisis kedua, nilai MSA dari variabel pengetahuan $\left(\mathrm{X}_{6}\right)$ juga kurang dari 0,50 yaitu sebesar 0,41 . Oleh karena itu, variabel pengetahuan harus dikeluarkan.

Nilai komunalitas adalah jumlah varian yang disumbangkan oleh satu variabel dengan variabel lainnya dalam analisis. Nilai eigenvalues semua variabel pada kolom initial bernilai satu. Hal tersebut membuktikan bahwa seluruh variabel dapat digunakan pada tahap pengujian berikutnya. Pada kolom extraction, nilai variabel rasa $\left(\mathrm{X}_{9}\right)$ terbesar yaitu 0,75 yang artinya sebesar 75,10 persen varians dari variabel rasa dapat dijelaskan oleh faktor yang terbentuk. Sebaliknya, nilai variabel pengaruh orang lain $\left(\mathrm{X}_{3}\right)$ terkecil, yaitu 0,40 artinya 40,50 persen varians dari variabel pengaruh orang lain dapat dijelaskan oleh faktor yang terbentuk. Penjelasan seterusnya untuk setiap variabel yang belum dijelaskan adalah sama, tetapi dengan ketentuan semakin besar nilai komunalitas sebuah variabel, maka semakin erat hubungannya dengan faktor yang terbentuk.

Pengujian selanjutnya untuk menentukan banyak komponen yang mungkin terbentuk berdasarkan eigenvalues pada total variance explained. Setelah dilakukan analisis, terhadap 10 komponen yang mewakili jumlah variabel initial eigenvalues yang ditentukan bernilai satu. Terdapat tiga komponen yang dominan, yaitu memiliki nilai eigenvalues lebih dari satu. Melihat persentase varian, secara manual dapat dihitung dengan membagi eigenvalues dengan jumlah komponen yang terbentuk dan dikalikan 100 persen. Nilai communalities analisis faktor dominan Beras Siger KWT Melati dapat dilihat pada Tabel 4.

Berdasarkan perhitungan, komponen pertama menyumbang sebesar 3,639/10 x 100\% $=36,39$ persen yang merupakan penyumbang dengan persentase tertinggi dan merupakan faktor dominan, faktor kedua menyumbang sebesar $1,448 / 10 \times 100 \%=14,48$ persen, dan faktor ketiga menyumbang sebesar $1,133 / 10 \times 100 \%=11,33$. 
Tabel 4. Nilai communalities analisis faktor dominan Beras Siger KWT Melati

\begin{tabular}{clcc}
\hline No & Keterangan & Initial & Extraction \\
\hline 1 & Pengaruh orang lain $\left(\mathrm{X}_{3}\right)$ & 1,00 & 0,41 \\
2 & Gaya hidup $\left(\mathrm{X}_{5}\right)$ & 1,00 & 0,65 \\
3 & Harga $\left(\mathrm{X}_{8}\right)$ & 1,00 & 0,71 \\
4 & Rasa $\left(\mathrm{X}_{9}\right)$ & 1,00 & 0,75 \\
5 & Warna $\left(\mathrm{X}_{10}\right)$ & 1,00 & 0,43 \\
6 & Aroma $\left(\mathrm{X}_{11}\right)$ & 1,00 & 0,75 \\
7 & Kekenyalan $\left(\mathrm{X}_{12}\right)$ & 1,00 & 0,59 \\
8 & Kemasan $\left(\mathrm{X}_{13}\right)$ & 1,00 & 0,65 \\
9 & Label $\left(\mathrm{X}_{14}\right)$ & 1,00 & 0,62 \\
10 & Kemudahan memperoleh & 1,00 & 0,68 \\
& $\left(\mathrm{X}_{15}\right)$ & & \\
\hline
\end{tabular}

Total ketiga faktor mampu menjelaskan variabel sebesar 62,19 persen. Hal tersebut menjelaskan bahwa 62,19 persen dari seluruh variabel yang ada dapat dijelaskan oleh tiga komponen yang terbentuk. Dengan demikian, nilai eigenvalues yang akan diambil adalah yang memiliki nilai $>1$ yaitu komponen 1, 2 dan 3 .

Jumlah komponen yang terbentuk juga dapat ditentukan dengan menggunakan scree plot. Scree plot adalah grafik yang terdiri dari eigenvalues sebagai sumbu vertikal dan banyaknya faktor sebagai sumbu horizontal. Penentuan jumlah komponen dapat dilihat dari titik plot yang berada di atas angka satu pada sumbu vertikal.

Scree plot yang terbentuk pada analisis komonen utama faktor dominan yang menentukan keputusan konsumen dalam pembelian Beras Siger dapat dilihat pada Gambar 1. Oleh karena itu, perlu dilakukan rotasi agar hasil komponen lebih jelas. Setelah dilakukan rotasi, beberapa variabel mengalami perubahan nilai faktor loadings. Rotate Component Matrix hasil dari proses rotasi Component Matrix memperlihatkan distribusi faktor (variabel) yang lebih jelas dan nyata. Dua komponen baru akan diberi nama dan

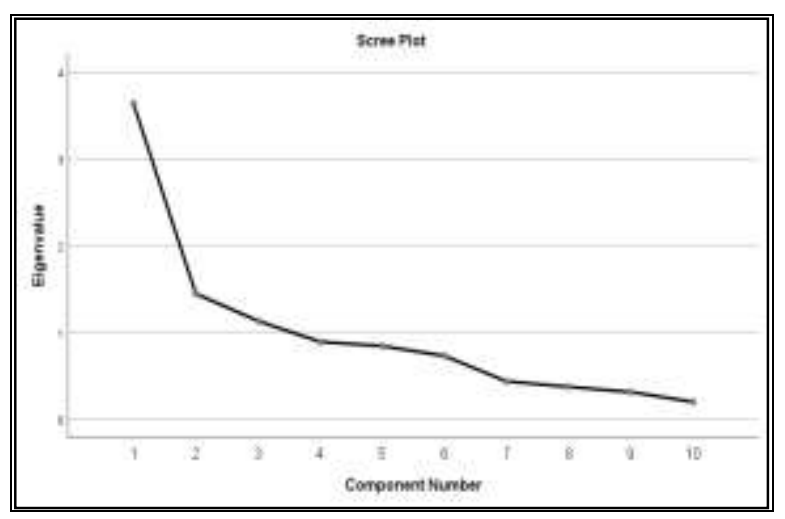

Gambar 1. Scree plot diinterpretasikan. Pemberian nama faktor, dapat dilakukan berdasarkan dua kriteria. Pertama pemberian nama faktor atas dasar nama-nama variabel penyusun yang menggabung menjadi satu kelompok. Ke dua, pemberian nama faktor atas dasar nilai factor loading tertinggi, sehingga penamaan faktor ini bersifat subyektif. Pemberian nama faktor atau komponen baru yang terbentuk dalam analisis faktor yang mempengaruhi keputusan konsumen dalam pembelian Beras Siger KWT Melati.

\section{Komponen Ke Satu (Faktor Kesesuaian Harga)}

Komponen pertama hasil analisis diberi nama faktor kesesuaian harga. Variabel pembentuk komponen ini memiliki keterkaitan antara produk dengan harga yaitu variabel harga $\left(X_{8}\right)$, rasa $\left(X_{9}\right)$, dan aroma $\left(\mathrm{X}_{11}\right)$.

Ketiga variabel penyusun komponen ke satu memiliki hubungan interaksi yang kuat. Dalam pembelian Beras Siger, konsumen memperhatikan harga, rasa, dan aroma dalam pencarian informasi dan evaluasi alternatif. Hal ini sesuai dengan teori yang dikemukakan oleh Philip Kotler bahwa harga merupakan faktor penting bagi konsumen sebagai bahan pertimbangan dalam membeli suatu produk.

Harga Beras Siger KWT Melati dinilai konsumen sebagai faktor yang memengaruhi dalam pembelian Beras Siger, karena harga menjadi penentu keputusan dalam pembelian. Jika harga sesuai kualitas yang dimiliki Beras Siger seperti rasa yang enak dan aromanya yang tidak khas, maka konsumen akan merasa puas.

\section{Komponen Ke Dua (Faktor Daya Tarik)}

Komponen ke dua hasil analisis diberi nama faktor daya tarik. Variabel pembentuk komponen ini memiliki keterkaitan dengan daya tarik konsumen yaitu variabel warna $\left(\mathrm{X}_{10}\right)$, label $\left(\mathrm{X}_{14}\right)$, dan kemudahan memperoleh $\left(\mathrm{X}_{15}\right)$. Variabel warna, label dan kemudahan memperolah memiliki keterkaitan satu sama lain. Ketiga variabel tersebut merupakan faktor yang dinilai konsumen memberikan pengaruh dalam pembelian Beras Siger. Warna Beras Siger yang menyerupai beras, serta label yang menarik memberikan informasi mengenai Beras Siger. Selain itu, ketersediaan Beras Siger yang selalu ada, menjadi daya tarik konsumen untuk melakukan pembelian.

Hasil penelitian ini sejalan dengan penelitian yang dilakukan Setiawan, Zakaria dan Indriyani (2016) 
menyatakan bahwa variabel label mempengaruhi konsumen, karena variabel tersebut menjadi pertimbangan-pertimbangan konsumen dalam pembelian beras organik.

\section{Komponen Ke Tiga (Faktor Kebiasaan)}

Komponen ke tiga hasil analisis diberi nama faktor kebiasaan. Komponen ini terbentuk dari empat variabel, yaitu pengaruh orang lain $\left(\mathrm{X}_{3}\right)$, gaya hidup $\left(\mathrm{X}_{5}\right)$, kekenyalan $\left(\mathrm{X}_{12}\right)$ dan kemasan $\left(\mathrm{X}_{13}\right)$. Keempat variabel tersebut merupakan faktor yang dinilai konsumen memberikan pengaruh dalam pembelian Beras Siger. Variabel gaya hidup memiliki nilai faktor loadings paling kuat dalam kategori ini. Hobi mengonsumsi Beras Siger yang dilakukan konsumen dapat disebabkan oleh pengaruh dari orang lain.

Pada umumnya, orang lain yang memberikan pengaruh dengan cara memberikan informasi yang penting tentang Beras Siger. Konsumen yang hobi mengonsumsi Beras Siger akan merasa ada yang berbeda pada saat tidak mengonsumsinya. Meskipun konsumen hobi mengonsumsi Beras Siger, konsumen juga mempertimbangkan kekenyalan dari Beras Siger dan kemasan. Kemasan merupakan faktor yang dinilai konsumen memberikan pengaruh dalam pembelian Beras Siger, karena sebagian konsumen berpendapat bahwa kemasan yang menarik dapat menunjukan kualitas dari Beras Siger.

\section{KESIMPULAN}

Berdasarkan skor analisis multiatribut sikap $\left(\mathrm{A}_{\mathrm{o}}\right)$ konsumen terhadap atribut Beras Siger di KWT sebesar 121,38. Atribut rasa mendapat skor sikap tertinggi sebesar 4,26 sementara atribut yang dinilai terendah adalah atribut kemudahan memperoleh dengan nilai sebesar 2,68. Proses pengambilan keputusan Beras Siger KWT Melati terdiri dari tahap pengenalan kebutuhan, tahap pencarian informasi, tahap evaluasi alternatif, tahap pembelian, dan tahap evaluasi pasca pembelian. Faktor-faktor dominan yang menentukan keputusan pembelian Beras Siger
KWT Melati yaitu kesesuaian harga, daya tarik, dan kebiasaan.

\section{DAFTAR PUSTAKA}

Ariesta W, Lestari DAH, dan Sayekti WD. 2016. Perilaku konsumen dan strategi pengembangan KWT Beras Siger Tunas Baru di Kelurahan Pinang Jaya Kemiling Kota Bandar Lampung. JIIA, 4 (3) : 326344. http://jurnal.fp.unila.ac.id/index.php/ JIA/article/viewFile/1508/1362. [17 Oktober 2017].

Kotler P dan Keller KL. 2009. Manajemen Pemasaran. Erlangga. Jakarta.

Mukti N, Utomo TP, dan Subekti. 2017. Analisis preferensi konsumen terhadap beras siger (Studi kasus di Kota Bandar Lampung). http//respository.iipm.unila.ac.id. [05 April 2019].

Parastry A, Lestari DAH, dan Prasmatiwi FE. 2017. Pengambilan keputusan dan sikap konsumen rumah tangga dalam membeli Beras Siger Toga Sari dan Mekar Sari. JIIA, 5 (2) : 192-199. http://jurnal.fp.unila.ac.id/ index.php/JIA/search/search?simpleQuery= Annisa+Parastry\&searchField=query. $\quad[07$ April 2019].

Pater JF dan Olson JC. 1999. Consumen Behavior Perilaku Konsumen dan Strategi Pemasaran. Terjemahan Damos Sihombing. Erlangga. Jakarta.

Setiawan A, Zakaria WA, dan Indriyani Y. 2016. Perilaku konsumen dalam pembelian beras organik produksi Kabupaten Pringsewu. JIIA, 4 (2) : 192-199. http://jurnal.fp.unila. ac.id/index.php/JIA/article/view/1237. [14 Februari 2018].

Sufren dan Natael Y. 2013. Mahir Menggunakan SPSS Secara Otodidak. PT Elex Media Komputindi. Jakarta.

Supranto. 2010. Analisis Multivariat Arti dan Interpretasi. Rineka Cipta. Jakarta.

Suryani T. 2012. Perilaku Konsumen Implikasi Terhadap Strategi Pemasaran. Graha Ilmu. Yogyakarta. 